\title{
Malignant blue nevus
}

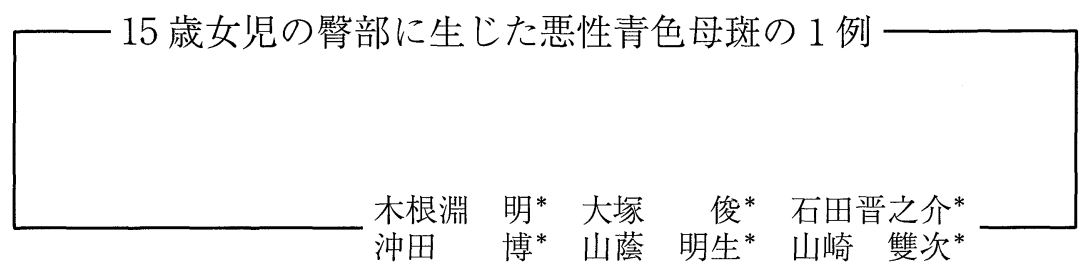

\section{Summary}

We report a 15-year-old girl patient with malignant blue nevus occurring on the right hip. Physical examination showed a black, partly shiny, round, hemisphered, slightly erosive, bleeding and elastic hard tumor, which was $51 \times 50 \times 13 \mathrm{~mm}$ in size, on the right hip and right inguinal lymph node swelling, which was $58 \times 29 \mathrm{~mm}$ in size. We initially diagnosed as nodular type of malignant melanoma. The relatively well-demrkated tumor and swallen lymph nodes were totally and widely removed and treated with pre-and post-operative chemotherapy. The lesion resulted in a histological diagnosios of malignant blue nevus. Immunohistrochemical studies showed positive reaction of malignant cells for s-100 and HMB-45. Serum 5-S-CD level is a good marker of prognosis for malignant blue nevus. We discuss cases of malignant blue nevus.

Key words : Malignant blue nevus

はじめに

悪性青色母斑は，細胞増殖性青色母斑が悪性 化した腫瘍と考えられており, Allen ら ${ }^{1)}$ が6例 を報告したのを嚆矢とする。現在までの報告例 は自験例を含めて国内外で57例に過ぎず，極め て稀な悪性腫瘍である。

今回我々は, 15 歳女児の䌓部に生じた悪性青 色母斑の 1 例を経験したので報告する。
* Akira KINEBUCHI, Shun OHTSUKA, Shinnosuke ISHIDA, Hirosi OKITA, Akio YAMAKAGE, Soji YAMAZAKI : 獨協医科大学皮膚科学教室
症例

患 者：15歳，女児

初 診: 平成 9 年 12 月 9 日

家族歴・既往歴：特記すべきことなし。

現病歴：幼少時より，右慰部に米粒大の黑色 斑あり。平成 9 年 11 月頃, 同部を打撲。その後, 黒色斑の急激な増大がみられたため当科を受診 した。

現 症: 右臀部に $51 \times 50 \times 13 \mathrm{~mm}$ 大, 半球状 隆起した，黒色光沢を有する，一部糜爛を伴い 易出血性，弾性硬の腫瘤を認めた（図 1 )。ま た, 右鼠径部に $58 \times 29 \mathrm{~mm}$ 大, やや黒青色に透 見される，弾性硬，圧痛のないリンパ節腫脹を 1 個認めた。 
治療および経過：臨床所見から結節型悪性黒 色腫を疑い, 入院後, DAV-フェロン 1 クール施 行後, 右篮部腫瘤を辺縁から $5 \mathrm{~cm}$ 離し, 皮下脂 肪織の深さまで切除し，右慰部より採皮した皮 膚を分層植皮し，右鼠径部リンパ節郭清術を施 行した。その後, 約 2 カ月間隔で, DAVフェロ ンを 4 クール施行。また，その間，胸部 X-P, 脳・胸部 ·腹部 $\mathrm{CT}, \mathrm{Ga}$ シンチ, 胃内視鏡, 注 腸等の検査を施行するも，右鼠径リンパ節への 転移以外, 転移を認めなかった。手術後の血清

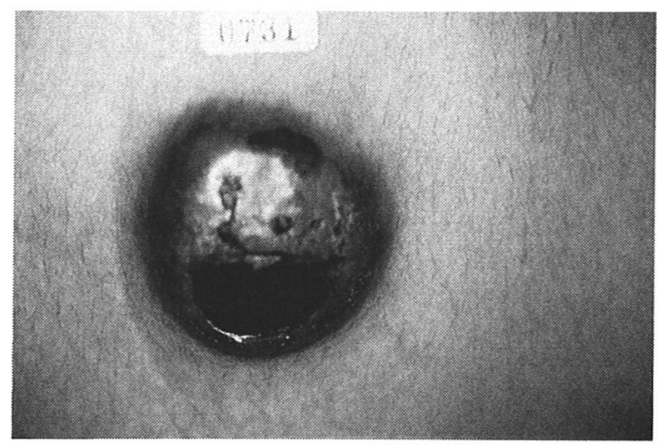

図 1. 初診時臨床像

半球状隆起した， $51 \times 50 \times 13 \mathrm{~mm}$ 大，黒色光沢 を有する, 一部糜爛を伴い易出血性, 弾性硬 の腫瘤
5-S-CD 值の経時的変化を表 1 に示す。血清 5-S$C D$ 值は, 腫瘍切除前に $29.8 \mathrm{nmol} / l$ と高值を示 したが，DAV-フェロン 1 クールと腫瘍切除後 には, $3.6 \mathrm{nmol} / l$ と正常值まで低下した。術後約 8 カ月を経過した現在，経過良好である。

組織所見: 原発巣の切除標本の HE 染色で は，表皮一真皮境界部より真皮深層まで及ぶ， メラノーマ細胞の増殖および多量のメラニンを 認め, 真皮深層では, 膠原線維間に異型性を伴 うメラノーマ細胞の増殖を認めた。右鼠径部り ンパ節も原発巣と同様の細胞の増殖を認めた。 免疫染色では, S-100 染色, HMB-45 染色陽性で あった。

以上より, Breslow's tumor thickness $28 \mathrm{~mm}$, Clark's level IV, T4N1M0, stage III の結節型悪 性黒色腫と診断した。

しかし, 日本皮膚悪性腫瘍学会報告時に, 斎 田教授などより，悪性青色母斑ではないかとの 指摘を受け, その後, 再検討した結果, 原発巣 の切除標本の HE 染色では, 腫瘍は真皮浅層か ら深層にかけて, 比較的境界明瞭な集塊を形成 し, 多数のメラニン顆粒を有する紡錘形の異型 メラノサイトの増殖とメラニン顆粒の少ない類

表 1. 血清 5-S-CD 值の経時的変化

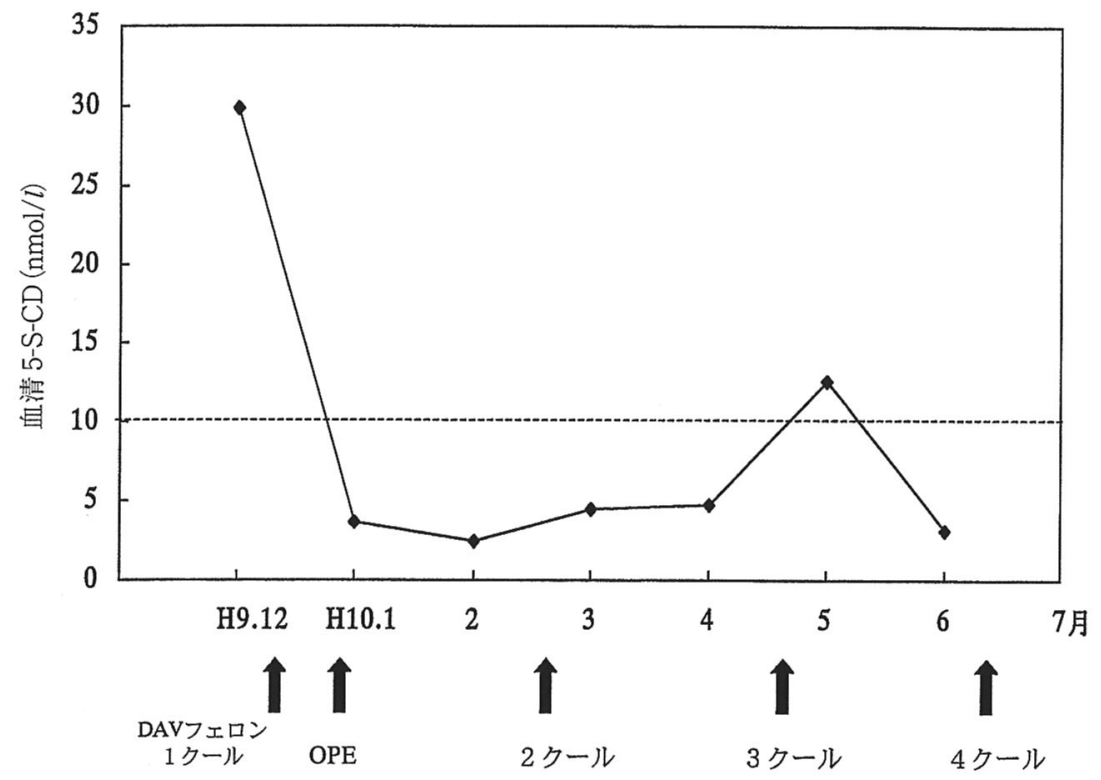




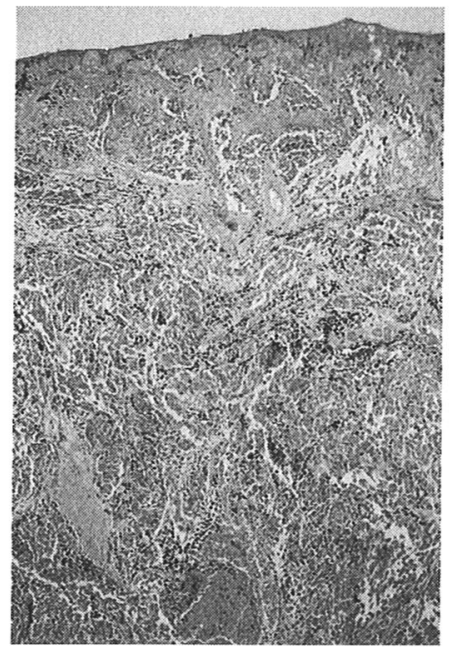

図 2. 原発巣組織所見 (H.E. 染色, 弱搪大像)

円形の異型細胞の集簇を認め（図 2，3 ), 右鼠 径部リンパ節でも, 原発巣と同様の細胞の増殖 を認めたため (図 4)，リンパ節転移を伴った悪 性青色母斑と診断した。

\section{考按}

悪性青色母斑は, 細胞増殖性青色母斑が悪性 化した腫瘍と考えられており，現在までの報告 例は，我々が調べた限りでは自験例を含めて本 邦 16 例 ${ }^{2)}$, 国外 41 例, 合計 57 例に過ぎず，極 めて稀な悪性腫瘍で，しかも確定診断の困難な 疾患である。

本症の臨床的特徵を，表 2 に示す。性別では 55 例が記載されており, 男性 26 例，女性 29 例 で男女差を認めなかった。初診時の年齢が明ら かなものは, 51 例で, 3 カ月から 80 歳と広範囲 にわたり，平均 40.7 歳であった。自験例は， 15 歳で発症しており，比較的若年発症であった。

発生部位では, 顔面頭部が 57 例中 30 例 （52.6\%）と半数以上を占め, 顔面頭部に好発す る傾向がある。次いで，背部，腰部に 12 例 （21.1\%）がみられ，その他大腿部，足背ないし 足底，上肢，胸部にそれぞれ数例ずつ認めた。

悪性青色母斑の発生母地として，なんらかの

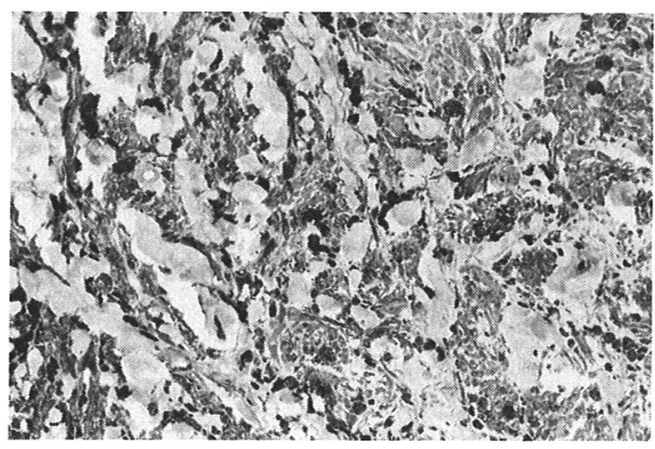

図 3. 原発巣組織所見 (H.E. 染色, 強拡大像)

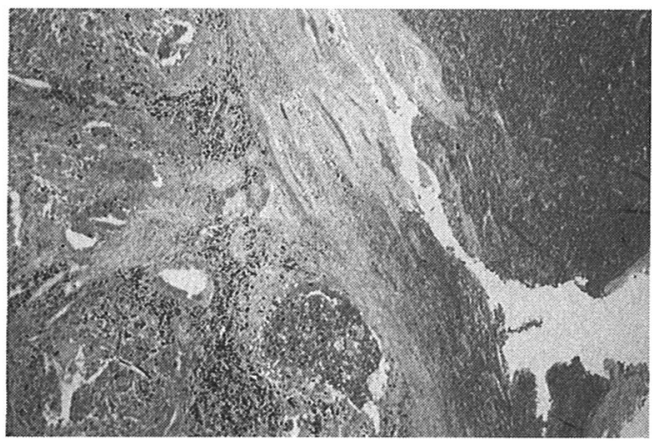

図 4．右鼠径部リンパ節（H.E. 染色）

皮膚病変がみられた例は，42 例（73.7\%）でそ のうち 35 例（61.4\%）が発生母地として青色母 斑を認めた。自験例では，発生母地として黒色 斑を自覚しており, おそらく青色母斑が先行し たものと推測される。

病変部の性状は，結節型のものが 57 例中 27 例 (47.4\%) と最も多く, また, 病変部の最大 径は，1 2cmのものが多くみられた。自験例 は，結節型で最大径が $5.1 \mathrm{~cm}$ と比較的巨大で あった。

悪性青色母斑のリンパ節転移は, 57 例中 29 例 (50.9\%) に認められた。悪性青色母斑の転 移はリンパ節の被膜，辺縁洞のみならず皮質， 髄質にもみられ，さらに腫瘍細胞によりリンパ 節内の構築もしばしば破壊されることがあ る ${ }^{3)}$ 。悪性青色母斑の予後については, 長期生 存例 ${ }^{4)}$ を認めることから, 悪性黒色腫と比較し て予後良好とする見解 (5) もあるが，57例中 21 例 （36.8\%）が腫瘍死に至っていることから，悪性 
表 2. 悪性青色母斑 57 症例のまとめ

\begin{tabular}{|c|c|c|c|c|c|}
\hline 性別 & 症例数 & 初診時年齢 & 症例数 & 発生部位 & 症例数 \\
\hline 男 & 26 & $0 \sim 10$ 歳 & 3. & 頭部、顔面 & 30 \\
\hline 女 & 29 & $11 \sim 20$ 歳 & 6. & 背部、腰部 & 12 \\
\hline \multirow[t]{9}{*}{ 不明 } & 2 & $21 \sim 30$ 歲 & 7 & 手部 & 3 \\
\hline & & $31 \sim 40$ 歳 & 9 & 大腿、下腿 & 3 \\
\hline & & $41 \sim 50$ 歳 & 7 & 足部 & 5 \\
\hline & & $51 \sim 60$ 歳 & 7 & 上腕、前腕 & 2 \\
\hline & & $61 \sim 70$ 歳 & 7 & 胸部 & 2 \\
\hline & & $71 \sim 80$ 歳 & 3 & その他 & 0 \\
\hline & & $81 \sim 90$ 歳 & 2 & & \\
\hline & & 不明 & 6 & & \\
\hline & & 平均 & 40.7 歳 & & \\
\hline 病変部最大径 & 症例数 & 発生母地 & 症例数 & 病変の性状 & 症例数 \\
\hline $1 \sim 2 \mathrm{~cm}$ & 10 & 青色母班 & 35 & 乓疹、結節型 & 27 \\
\hline $2 \sim 3 \mathrm{~cm}$ & 4 & 太田母斑 & 4 & 斑状、局面型 & 9 \\
\hline $3 \sim 4 \mathrm{~cm}$ & 2 & 母斑細胞母斑 & 3. & 混合型 & 12 \\
\hline $4 \sim 5 \mathrm{~cm}$ & 4 & 不明 & 15 & 不明 & 9 \\
\hline \multicolumn{6}{|l|}{$5 \sim 6 \mathrm{~cm}$} \\
\hline \multicolumn{6}{|l|}{$6 \mathrm{~cm}$ 以上 } \\
\hline 不明 & 31 & & & & \\
\hline 経過観察期間 & 症例数 & リンパ節転移 & 症例数 & 予後 & 症例数 \\
\hline ～1年 & 12 & あり & 29 & 生存 & 20 \\
\hline $1 \sim 3$ 年 & 11 & なし & 9 & 死亡 & 21 \\
\hline $3 \sim 5$ 年 & 5 & 不明 & 19 & 不明 & 16 \\
\hline \multicolumn{6}{|l|}{$5 \sim 10$ 年 } \\
\hline 10 年以上 & 5 & & & & \\
\hline 不明 & 17 & & & & \\
\hline
\end{tabular}

黒色腫と同様かむしろ悪いのではないかと考え られる。

悪性黒色腫は，メラニン形成という分化形質 を有しており，これを利用してその病態を把握 しようとする試みがいくつか報告 ${ }^{67)}$ されてい る。メラニン関連代謝物のうち, 特に5-S-CDの 尿中排泄は，転移巣の早期発見に有用であると いわれ，生化学的腫瘍マーカーとして利用され てきたが，最近，尿中 5-S-CD よりも血清 5-SCD のほうが悪性黒色腫の進展度の指標として 優れているとする報告 ${ }^{8)}$ がある。悪性青色母斑 において，5-S-CD に関連する報告は，ほとんど

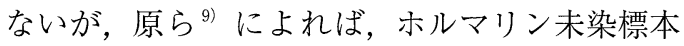
の組織中の 5-S-CD 值を測定したところ，有意 に高値を示したと報告している。自験例では, 血清 5-S-CD を測定したが, 術前の血清 5-S-CD 值は, $29.8 \mathrm{nmol} / l$ と高值を示したが, DAV-
フェロン 1 クールと腫瘍切除後には, $3.6 \mathrm{nmol} / l$ と正常值まで低下した。血清 5-S-CD值は, 覀性 黒色腫と同様に悪性青色母玟においても，進展 度を鋭敏に反映する生化学的マーカーであると 考えられ，術後正常值を示していた血清 5-S$\mathrm{CD}$ 值が，正常上限を超えて上昇した場合，悪 性青色母斑の再発・転移を考えるべきである。

悪性青色母斑の治療については症例が少ない ことから確立されていないが，まずは外科的切 除を行い, 術後の化学療法については, 悪性黒 色腫に準じて多剂併用療法を用いる報告 ${ }^{3)}$ 10) 11) が多い。今後，症例の積み重ねによる検討が必 要と思われる。

\section{文献}

1) Allen, A. C., Spitz, S. : Malignant Melanoma : A 
clincopathological analysis of the criteria for diagnosis and prognosis. Cancer, $6: 1-45,1953$.

2）佐藤敬子, 影下登志郎, 小野友道, 他 : 覀性青色 母斑の1例. 日皮会誌，95:1461-1467, 1985.

3) 前嶋啓孝, 橋本秀樹, 安斎真一, 他: 悪性青色母 斑の1例. 臨皮, 47:1243-1248, 1993.

4) Lund, H. Z. \& Kraus, J. M. : Melanotic tumors of the skin. Atlas of Tumor Pathology, sec. 1, fasc. 3. Washington, D. C., AFIP, 104-121, 1962.

5) Reiss, R. F., Gray, G. F. : Malignant blue nevus : Occurrence with aggressive behavior, New York State, J. Med., 75: 1749-1751, 1975.

6) Agrup, G. : Urinary excretion of 5-S-cysteinyldopa in patients with primary melanoma or melanoma metastasis. Acta Dermatovenereol (Stockholm), $55: 337-341,1975$.
7）森嶋隆文: 悪性黒色腫の5-S-Cysteinyldopa によ る診断. Skin Cancer, 10:9-19, 1995.

8）堀越貴志, 伊藤祥輔, 若松一雅, 他：血清 5-S-CD の変動と悪性黒色腫の予後. Skin Cancer, $6: 304-$ 308, 1991.

9）原弘之, 森嶋智津子, 下島博之, 他: 覀性青色母 斑一ホルマリン未染標本, HMB-45免疫染色, 組 織中 5-S-Cysteinyldopa 值抒よび細胞增殖能の検 討を加えて一 (会議録). 日本皮虐科学会雑誌, $105: 386,1995$.

10）福井良昌, 松本義也:Malignant Blue Nevus. 西日 皮膚, $51: 1129-1133,1989$.

11）日笠寿, 井上裕史, 熊谷嘉隆, 他：乳房腫瘤とし て発見された悪性青色母斑の1例. 日形外会誌, $14:$ 435-441, 1994. 